NBER WORKING PAPER SERIES

\title{
DOES TEACHER TESTING RAISE TEACHER QUALITY? EVIDENCE FROM STATE CERTIFICATION REQUIREMENTS
}

\author{
Joshua Angrist \\ Jonathan Guryan \\ Working Paper 9545 \\ http://www.nber.org/papers/w9545 \\ NATIONAL BUREAU OF ECONOMIC RESEARCH \\ 1050 Massachusetts Avenue \\ Cambridge, MA 02138 \\ March 2003
}

This paper was prepared for the October 2002 conference in honor of Orley Ashenfelter's 60th birthday. Orley's many contributions include early research on wage determination and unions in the public sector. The authors thank Nate Baum-Snow, Naveed Khawaja, Andrew Kolesnikov and Nirupama Rao for excellent research assistance. The confidential data used in this paper were provided by the National Center for Education Statistics, U.S. Department of Education. This work is supported by the Centel Foundation/Robert P. Reuss Faculty Research Fund at the Graduate School of Business, the University of Chicago. The views expressed herein are those of the authors and not necessarily those of the National Bureau of Economic Research.

(C)2003 by Joshua Angrist and Jonathan Guryan. All rights reserved. Short sections of text not to exceed two paragraphs, may be quoted without explicit permission provided that full credit including Cnotice, is given to the source. 
Does Teacher Testing Raise Teacher Quality? Evidence from State Certification Requirements Joshua Angrist and Jonathan Guryan

NBER Working Paper No. 9545

March 2003

JEL No.J45, J48, J31, J24

\section{$\underline{\text { ABSTRACT }}$}

The education reform movement includes efforts to raise teacher quality through stricter certification and licensing provisions. Most US states now require public school teachers to pass a standardized test such as the National Teacher Examination. Although any barrier to entry is likely to raise wages in the affected occupation, the theoretical effects of such requirements on teacher quality are ambiguous. Teacher testing places a floor on whatever skills are measured by the required test, but testing is also costly for applicants. These costs shift teacher supply to the left and may be especially likely to deter high-quality applicants from teaching in the public schools. We use the Schools and Staffing Survey to estimate the effect of state teacher testing requirements on teacher wages and teacher quality as measured by educational background. The results suggest that state-mandated teacher testing increases teacher wages with no corresponding increase in quality.

\author{
Joshua D. Angrist \\ MIT Department of Economics \\ 50 Memorial Drive \\ Cambridge, MA 02142-1347 \\ and NBER \\ angrist@mit.edu
}

\author{
Jonathan Guryan \\ University of Chicago Graduate School of Business \\ 1101 E. 58th St \\ Chicago, IL 60637 \\ and NBER \\ jonathan.guryan@gsb.uchicago.edu
}


Economists, educators, and policymakers generally agree that better teachers are likely to lead to better schools. But the question of how to attract better teachers remains open. A natural economic solution is to raise teacher pay. From 1960 to 1998 , teacher salaries rose in real terms by 43 percent, outpacing nonteacher salaries. At the same time, the IQ scores of those who chose to teach fell, and evidence on the relationship between salaries and measures of teacher quality or performance is mixed (Hanushek, Kain, and Rivkin, 1999; Murnane, et al, 1991; Figlio, 2002).

Beginning in the 1960's, states began testing prospective teachers in a direct effort to ensure teachers meet minimum standards for basic skills and subject knowledge. ${ }^{1}$ By 1999, 43 states required applicants to pass some sort of standardized certification test such as the National Teacher Examination or Praxis examinations published by the Educational Testing Service. ${ }^{2}$ Although there is some reciprocity in the form of probationary and provisional licensing, states relying on tests typically require newly employed teachers to pass their own tests even if they are licensed in other states. As a theoretical matter, the impact of such testing is ambiguous. Test requirements may establish a minimum achievement standard, as their proponents argue, but certification requirements may also deter applicants from choosing to teach. Moreover, stricter certification procedures may be seen as especially costly hurdles by experienced teachers or teachers with attractive employment options in other fields.

In this paper, we estimate the impact of state-mandated certification tests on teacher quality. Data

${ }^{1}$ Testing of teachers is not a new phenomenon. Teachers were tested in basic subjects in many states in the $19^{\text {th }}$ century and at the beginning of the $20^{\text {th }}$ century. However, in most states the tests were graded and certificates were issued at the county level. In the early part of the $20^{\text {th }}$ Century a number of states began more widespread use of testing for certification. But World War II led to a decrease in teacher supply and a subsequent increase in hiring of teachers with alternative certification. As a result, most states had discontinued the use of required teacher testing by the end of the war.

${ }^{2}$ Since 1998, the ETS National Teachers Examination widely used to certify Education School graduates for work as teachers has been known as the Praxis II and is part of a series that includes Praxis I, also known as the PreProfessional Skills test (PPST) which is used to screen applicants to Education Schools, and a series of classroom performance assessments known as Praxis III. Many states (e.g., Minnesota as of September 2001) require both Praxis I and Praxis II. As of this writing, sample Praxis content is available at http://www.ets.org/praxis/download.html. The Praxis examinations consist of dozens of subtests. Each state selects their own credentialing requirements. Some states, such as California, require a combination of Praxis tests and locally developed tests, others, such as Massachusetts, rely on a locally developed exam only. 
for our study come from the Schools and Staffing Survey (SASS), a nationally representative repeated crosssection of teachers and schools, initially conducted during the 1987-88 school year and most recently available for 1999-2000. This sample coverage is useful since testing requirements have grown most sharply in recent years. In addition to providing information on teacher salaries, the 1987-88, 1993-94, and 19992000 waves of SASS include measures of teacher educational background that we take to be indicators of teacher quality. We first show that the impact of state provisions on the prevalence of teacher testing is about 50 percentage points. Consistent with the notion that certification requirements establish barriers to entry, we also find that teacher testing increases teacher salaries. On the other hand, we find no evidence that testing increases the quality of colleges attended by new teachers or the likelihood that teachers teach material studied in college or graduate school.

\section{BACKGROUND}

A 1986 report of the Carnegie Task Force on Education and a follow-up report released in 1996 called for the introduction of more centralized systems of certification for public school teachers. A policy of stricter and more centralized teacher licensing has also been supported by the National Education Association and a range of groups promoting education reform (Ballou and Podgursky, 2000). Proposed licensing systems involve the accreditation of education programs, longer apprenticeships, and teacher testing. Proponents of teacher licensing point to the spread of medical licensure in the early $20^{\text {th }}$ Century as evidence that licensing raises professional standards. On the other hand, economists have long warned that licensing and certification are potentially cost-raising barriers to entry (see, e.g., Friedman and Kuznets, 1945). Moreover, there is little hard evidence for any consumer benefits of mandatory occupational licensing, even in medicine. In this paper, we attempt to estimate the impact of what is perhaps the simplest component of teacher licensing provisions, a requirement that teachers pass a certification test that can be seen as analogous to medical boards and legal bar exams. 
In a recent survey of research on occupational licensing, Kleiner (2000) observes that more American workers are affected by licensing requirements than belong to unions or are covered by the minimum wage. Yet there are remarkably few studies of the impact of licensing on wages or productivity. Standard economic arguments suggest licensing provisions are likely to affect economic outcomes through a number of channels. First, occupational licensing may provide a signal of worker quality and help to maintain quality standards when information about quality is imperfect. Indeed, this is the stated rationale for government-imposed licensing requirements. As Kleiner (2000) notes, however, the evidence of consumer benefits from most licensing requirements is thin or nonexistent. In addition, mandatory licensing requirements impose a barrier to occupational entry that is likely to increase wages in the licensed occupation. ${ }^{3}$

One of the few previous attempts to estimate the effect of licensing requirements is a study of teachers by Kleiner and Petree (1988), who link state licensing requirements with average teacher pay, pupils' SAT and ACT scores, and high school graduation rates. Their results show no clear relationship between licensing and pupil achievement or teacher pay, though there is a robust negative relationship between licensing and pupil-teacher ratios. The authors attribute the ambiguous results on licensing to the weak licensing provisions in force during their sample period. The recent strengthening of state teacher licensing provisions may provide stronger evidence on licensing effects. Another related study is Goldhaber and Brewer (2000), who link student achievement with state teacher licensing and testing requirements. Their analysis does not exploit changes in state provisions over time, and the effects of testing enter only as interactions with other licensing provisions. Consistent with the entry-barriers story, Hanushek and Pace (1995) find that state requirements for courses and tests significantly lower the probability prospective teachers complete training, again using cross-state variation.

Most studies of the economic consequences of occupational licensing look at the medical and dental

\footnotetext{
${ }^{3}$ The literature on occupational regulation distinguishes between mandatory licensing such as that required of medical professionals and voluntary certification such as that sometimes obtained by auto mechanics.
} 
professions. In a study of dentistry, for example, Kleiner and Kudrle (2000) found that people in states with strictly regulated entry to dentistry had dental health that is no better than those in states with less regulation. Dental regulation, however, does appear to increase both the hourly earnings of dentists and consumers' cost of dental care. ${ }^{4}$ Similarly, in a recent study of immigrant physicians in Israel, Kugler and Sauer (2003) found that immigrant physicians who obtained a license to practice medicine in Israel had sharply higher earnings than those who did not. At the same time, a comparison of OLS and instrumental variables (IV) estimates of the effect of licensing suggests that doctors who obtain licenses and end up practicing medicine have lower earnings potential than those who do not. Thus, licensing appears to reduce average quality. It should be noted, however, that teachers differ from medical professionals in that they are more likely to work in the public sector. Certification may be more necessary to reveal worker quality in the absence of the market forces more likely to operate in the private sector.

\section{THEORETICAL FRAMEWORK}

Although the theoretical impact of teacher testing on wages seems clear cut, the effect of testing on quality is less so. The policy objective that motivates teacher testing, as with other worker screening devices, is to identify and hire those most qualified to teach. In practice, however, the design of effective testing strategies is difficult since tests are noisy predictors of worker quality. Moreover, testing is costly for employers and employees. Teacher supply therefore shifts as salaries must compensate workers for their time and effort in being tested. Finally, risk averse workers will view employment offers that are contingent on stochastic test results as less attractive than unconditional offers.

A large theoretical literature has looked at the impact of worker screening mechanisms on wages and job assignments. We use basic elements of the Gausch and Weiss $(1980,1981)$ setup to discuss the possible

${ }^{4}$ Licenses for dentistry appear to be the most widely studied in research on licensure. See Kleiner and Kudrle (2000) for references to earlier work on dentists. Kleiner (2000) also compares wages in licensed occupations with wages in unlicensed occupations requiring approximately the same level of education and training. 
implications of standardized testing for teacher quality. ${ }^{5}$ Because school districts are not necessarily profit maximizers or even costs minimizers, we focus on the impact of test-based hiring standards on teachers' labor supply, as opposed to the more complex question of how worker testing affects equilibria in competitive markets.

Suppose an applicant for a teaching job can earn an alternative wage, $w_{\mathrm{i}}$, and teachers are paid $w$. Applicants must be tested to get a job, a process which they view as costing an amount $c$. We can think of $c$ as a monetary cost or as the cost of time and effort directed towards preparation and completion of the test. More generally, testing might involve a probationary period, in which case any wage reduction during the probationary period is part of the testing cost.

Worker $i$ passes the test with probability $p_{\mathrm{i}}$. We presume the test has some screening value, so that $p_{\mathrm{i}}$ and $w_{\mathrm{i}}$ are positively correlated. In other words, higher quality applicants, as measured by outside earnings potential, are more likely to pass the test. Assuming teachers maximize expected utility with von NeumannMorgenstern utility of income $\mathrm{U}(\bullet)$, applicant $i$ must be offered a wage that satisfies

$$
p_{\mathrm{i}} \mathrm{U}(w-c)+\left(1-p_{\mathrm{i}}\right) \mathrm{U}\left(w_{\mathrm{i}}-c\right) \geq \mathrm{U}\left(w_{\mathrm{i}}\right)
$$

if he or she is to find it worth applying. Clearly with a higher $c$, the wages offered teachers, $w$, must be higher to obtain an applicant pool of the same quality. This is the entry-barrier effect on wages; positive $c$ reduces the supply of applicants, holding the underlying distribution of quality level $w_{\mathrm{i}}$ fixed. Note also that this effect is larger with risk averse than with risk-neutral applicants. Risk-neutral applicants require only that $p_{\mathrm{i}}\left(w-w_{\mathrm{i}}\right) \geq c$.

How does testing affect average quality? Continuing to think of quality as indexed by the alternate wage, $w_{\mathrm{i}}$, suppose that school boards would like to select applicants with $w_{\mathrm{i}} \geq \bar{w}$. For simplicity, suppose also that applicants are risk neutral and that the certification test can be designed so that $p_{\mathrm{i}}=1$ if $w_{\mathrm{i}} \geq \bar{w}$ and is zero

${ }^{5}$ See also Lelande (1979). For more recent and more elaborate models along these lines, see, e.g., Wand (1997) and Wang and Weiss (1998). 
otherwise. Then average teacher quality in the testing regime is

$$
\mathrm{E}\left[w_{\mathrm{i}} \mid w-c>w_{\mathrm{i}} \geq \bar{w}\right] .
$$

This average can be compared with the average teacher quality without testing, which is equal to $\mathrm{E}\left[w_{\mathrm{i}} \mid w>\right.$ $w_{\mathrm{i}}$. Clearly the quality comparison depends on how $w$ and $c$ are determined. The imposition of a lower bound, $\bar{w}$, tends to increase quality. But if testing is viewed as very costly, so that the net teacher wage in the testing regime, $w-c$, is less than the teacher wage without testing, average quality may decline. This decline in average quality occurs in spite of the fact that the lower quantiles of the quality distribution will have increased if testing is effective.

The notion that costly and time-consuming certification requirements limit teacher supply or adversely affect teacher quality is behind education reform efforts promoting "alternative certification" paths for public school teachers. Many researchers have noted that even though salaries tend to be higher in public schools than private schools, bureaucratic and costly certification requirements may send the best teachers to private schools, where these requirements are not imposed (e.g., Goldhaber and Brewer, 2000). Note also that if $c$ includes the opportunity cost of time invested in test preparation and test taking, then testing costs will be an increasing function of $w_{\mathrm{i}}$, further eroding the quality-enhancing effect of the lower bound, $\bar{w}{ }^{6}$ Finally, the discussion here presumes that teacher testing is of great value in predicting teacher quality. While the National Council for the Accreditation of Teacher Education (1997) promotes this view, it seems likely that the question of what teachers should know is not entirely clear-cut. In practice, those with $w_{\mathrm{i}} \geq \bar{w}$ may not actually be more productive in the classroom.

\footnotetext{
${ }^{6}$ Alternately, applicants with higher $w_{i}$ may also be better test-takers, implying $c$ and $w_{i}$ are negatively correlated. Then increased costs will tend to deter lower the average $w_{i}$ among applicants. The size of the net effect of testing is the empirical question addressed below.
} 


\section{DATA AND DESCRIPTIVE STATISTICS}

Data for this study come from the Teacher Demand and Shortage Survey (TDSS), a component of the Schools and Staffing Survey (SASS), which links information on school districts, teachers, and students. The first round of the SASS was in the 1987-88 school year, followed by rounds in 1990-91, 1993-94, and 1999-2000. The core survey in the SASS is a complex stratified sample of schools, drawn largely from the Department of Education's Common Core of Data (CCD) which is an administrative roster of schools from state education agencies. Data for the TDSS come from surveys distributed to superintendents of Local Education Agencies (LEAs; essentially, school districts) containing sampled schools. In addition, teachers in sampled schools complete a Teacher Survey. Other components of the SASS, not used here, include a School Principal Survey, a Teacher Follow-up Survey, and a collection of student records (in 1993-94 only). Our estimates use the weights provided with the TDSS to make sample statistics representative of US school districts. $^{7}$

Information on district testing requirements comes from the TDSS, as do other characteristics of the district such as starting salaries and district size. In addition, we aggregate responses to the teacher survey up to the district level to provide district-level measures of teacher characteristics and quality such as the proportion of teachers who teach in their subject. We also match quality measures such as the average SAT score in the teachers' undergraduate institution from the Higher Education Research Institute to the SASS LEA file. Although these quality measures are not as detailed as we would like, average SAT score of undergraduate institution is a frequently used measure of new teacher quality (see, e.g, Figlio, 2002). Finally, we collected information on state testing requirements for each survey year from published summaries. ${ }^{8}$ The sample used here excludes districts with less than 50 pupils, below about the first percentile in the district size distribution. The sample includes public schools only and omits charter schools in the last year

\footnotetext{
${ }^{7}$ About one-third of districts appear in a subsequent round but we ignore this in the statistical analysis.

${ }^{8}$ For a list of sources used to compile state testing requirements, see the data appendix.
} 
(typically, each charter school is its own district). For additional details on the construction of the sample and variable definitions, see the data appendix.

\section{Descriptive statistics}

Table 1 reports descriptive statistics by survey year. Each round contributes almost 5,000 districts. The average district size is about 3,000 pupils and 160 teachers. The table also shows the proportion of districts with inexperienced teachers, defined as those hired in the last 3 years (preceding the survey) and the proportion of districts with teachers hired in the past year. Over 40 percent of districts have inexperienced teachers and almost 20 percent have hired teachers in the past year. In the analysis below, we report results separately for the full sample, and for the 3-year and 1-year samples, since testing requirements may have a bigger impact in districts that have recently been hiring.

The first outcome variable used to measure the impact of teacher testing is teacher wages. Although the theoretical discussion suggests the effect of testing on the distribution of teachers' alternate wages is ambiguous, the effect on teachers' wages is likely to be positive since testing restricts supply (note that $w-c$ has to exceed the quality threshold). The SASS reports the wages paid to teachers in each district by schooling and experience level, i.e., for teachers with a Bachelor's degree (B.A.), with a Master's degree (M.A.), and with a Master's degree plus 20 or more years of experience. The table shows teacher wages for those with a B.A. of around 25,000-26,000 (1999 dollars). Wages went up between 1993-94 and 1999-2000. Wages are also about 10 percent higher for those with an M.A., and much higher for experienced teachers with a Master's degree.

To measure teacher quality we look at the average SAT scores of teachers' undergraduate institution, whether the institution is coded as a research university or liberal-arts college, the proportion of teachers with alternative state certification, and the proportion of teachers with a degree in the subject they teach. Note that the SAT and Carnegie variables cannot be linked to the 1990-91 SASS since this round did not identify 
teachers' undergraduate institutions. The college-based quality variables show fairly stable quality over the sample period. In contrast, there is an increase in the proportion of inexperienced and new teachers with alternative certification, and an increase in the proportion of teachers who have a degree in the subject they teach. Finally, the table provides descriptive information for other characteristics of the teacher workforce that might be affected by licensing. This includes the sex, race, and Hispanic ethnicity distribution among all teachers and recently hired teachers.

\section{Testing prevalence and requirements}

The proportion of districts subject to a state-mandated basic skills test requirement increased from just over $40 \%$ in $1987-88$ to $70 \%$ in 1993-94. This can be seen in the first row of Table 2, which reports the prevalence of state test requirements based on our match of information for each state to the SASS. Although the number of districts requiring a basic skills test fell slightly between 1993-94 and 1999-2000, the number of states requiring tests continued to increase and reached two-thirds. ${ }^{9}$ Fewer states required a subject test than required a test of basic skills in 1987, but this requirement also saw a dramatic and steady increase, so that the proportion requiring subject and basic skills tests were about equal by 1999 . By 1999 , over $80 \%$ of districts faced some kind of state-mandated test requirement.

In addition to using published state testing requirements, we analyzed SASS questions put to district administrators about the use of testing. In particular, the following two questions are relevant:

Do you require or use information on whether an applicant passed a STATE test of basic skills?

Do you require or use information on whether an applicant passed a STATE test of subject knowledge?

SASS respondents (i.e., officials completing the SASS on behalf of the district) answered with:

\footnotetext{
${ }^{9} \mathrm{~A}$ few large states reversed their basic skills testing requirements so the proportion of districts requiring testing dipped between 1993 and 1999.
} 
Require;

Use, but not require;

Do not use.

Rows 4, 5, and 6, in Table 2 show the proportion of districts which report they require state tests. Surprisingly, this proportion is below the proportion of districts who were subject to a state-mandated test requirement.

The difference between state testing requirements and districts' reported testing practices seems most likely to be due to inaccurate responses and misunderstandings of SASS questions related to applicant screening. We substantiated this hypothesis by surveying a sample of districts. In particular, we administered the applicant-qualifications portion of the 1999-2000 SASS to 211 "dissonant districts" , defined as those where SASS responses to questions on testing conflicted with state requirements. ${ }^{10}$ In response to our survey, only 13 percent of districts reported they neither use nor require a state test of basic skills while only 17 percent reported they neither use nor require a state test of subject knowledge. On further inquiry with some districts, we discovered that where tests are required, districts may waive this under difficult hiring conditions, but typically still hope to "use the test". An occasional source of confusion, however, had to do with the definition of a "state requirement" or a "state test". For example, the state may require ETS's Praxis exam, not strictly speaking a state test along the lines of, say, the test developed and used by districts in the state of Massachusetts. In any case, the majority of districts in our sample appeared to be trying to follow state testing mandates.

The last three rows show the proportion of districts using tests based on a variable constructed by recoding the response to SASS test-use questions to be consistent with state requirements (e.g., districts who

\footnotetext{
${ }^{10} \mathrm{~A}$ district was determined to be dissonant if the response to both the basic skills and subject test questions indicated no test requirement and no test use while the state required testing. We sampled up to 10 dissonant districts in any state with dissonant districts. Of the 322 districts sampled, we obtained responses from 211 districts for a response rate of 66 percent. In each district surveyed, we attempted to contact "the director of personnel or someone knowledgeable about personnel policies in the district." The original sample contained 7 vocational districts and one charter district, so these factors cannot account for reporting conflicts.
} 
report not using a subject test in a state that requires subject testing were recoded as using a subject test). Not surprisingly, these recoded variables have higher means than the raw SASS responses in the second three rows. They also show a consistent pattern of increasing test use over time. The impact of state requirements on testing is gauged on the basis of these recoded variables.

\section{Effects of state testing requirements on testing}

The impact of state testing requirements on test use is summarized by regressing dummies for test use on dummies for state mandates, along with state and year main effects, dummies for urban, suburban, and rural districts, district enrollment, district fraction minority enrollment, and a quadratic in the state unemployment rate. In particular, Table 3 reports estimates of the coefficients $\alpha_{1}$ and $\alpha_{2}$ on basic skills and subject test mandate dummies, $\mathrm{b}_{\mathrm{jt}}$ and $\mathrm{s}_{\mathrm{j} t}$, in the equation

$$
\mathrm{y}_{\mathrm{ijt}}=\mu_{\mathrm{s}}+\delta_{\mathrm{t}}+\mathrm{X}_{\mathrm{ijt}}{ }^{\prime} \beta+\alpha_{1} \mathrm{~b}_{\mathrm{jt}}+\alpha_{2} \mathrm{~s}_{\mathrm{jt}}+\epsilon_{\mathrm{ijt}},
$$

where $\mathrm{y}_{\mathrm{ijt}}$ is an indicator for district requirements, $\mu_{\mathrm{s}}$ and $\delta_{\mathrm{t}}$ are state and year effects, and $\mathrm{X}_{\mathrm{i}}$ is the vector of other covariates (including individual district controls and the state-level unemployment rate). Some of the models combine the separate basic skills and subject dummies into a single dummy for any test.

Even in states that do not require testing, many districts use tests. Estimates of equation (3) can therefore be seen as a measuring the difference between test use with and without requirements. Table 3 shows that state-mandated basic skills testing increases the likelihood of basic skills testing in school districts by about 50 percent. As can be seen in column 2, subject test requirements are also correlated with the use of basic skills tests, but column 3 shows that when both dummies are included, the basic skills requirement dominates. The reverse pattern appears in columns 5-7 for models with the use of subject tests on the left hand side. The imposition of any test requirement also increases the likelihood of testing by about 50 percent. Moreover, as the lower two-thirds of Table 3 shows, these effects are similar when the sample of districts is limited to those that have new or inexperienced teachers. 


\section{EFFECTS ON WAGES}

State testing requirements are associated with slightly higher wages. This can be seen in Table 4a, which reports estimates of equation (3) for models with the log of teacher salaries on the left hand side. Many of the estimated salary effects are significant. For example, column 1 shows that the salaries of teachers with a B.A. degree are about 2.4 percent higher when states require a test of basic skills, an effect estimated with a standard error of $.009 .{ }^{11}$ Subject test requirements also appear to be associated with higher wages, though the estimated effects of testing requirements are not significant when both the subject and basic skill testing variables are entered at the same time.

Most new teachers have a B.A. As the estimates in columns 5-8 and 9-12 show, however, state testing requirements are also associated with higher wages for teachers with an M.A. and for experienced teachers with an M.A. Since teachers with more advanced degrees and more experience are less likely to have been hired recently, these effects may reflect the maintenance of relative wages by shifting the entire pay scale in response to testing requirements. It should also be noted that in some states that require tests for new hires, experienced teachers are subject to periodic re-certification tests as well.

An alternative interpretation of the increase in wages for more educated or more experienced teachers is that these effects reflect some sort of omitted variables bias. The possibility of omitted variables bias is also raised by the fact that the estimated wage effects are similar in the full sample and the samples of districts with inexperienced and new-teachers. Because testing requirements are time-varying state-level variables, the most likely source of bias is some sort of state-specific trend in teacher wages in states that adopt testing requirements. Therefore, as a specification check we re-estimated the wage equations using a model that adds state-specific linear trends to specification (3). This controls for the fact that teacher wages may be increasing due to secular trends such as a growing economy that contribute to the demand for

\footnotetext{
${ }^{11}$ The regression estimates reported here and elsewhere in the paper were weighted using district sampling weights. Standard errors are corrected for state-year clustering.
} 
higher entry barriers. One possibility, for example, is that unions raise entry barriers in good times. On the other hand, our survey of district personnel officers suggests districts and therefore perhaps also states want to weaken formal requirements when teachers are hard to find. ${ }^{12}$

The results of estimating equation (3) with state-specific linear trends, reported in Table 4b, show even stronger wage effects than appear in Table 4a. For example, the imposition of a state test of basic skills is associated with roughly $3.3 \%$ higher wages for teachers with a B.A., a precisely estimated effect. Moreover, the effects of requiring tests of basic skills and subject matter remain significant when entered jointly. The fact that estimates with state trends are larger is consistent with the view that testing provisions are weakened in a strong economy. Most importantly, the pattern of effects is now more consistent with a causal interpretation that attributes higher wages to the impact of state testing regulations. In particular, the effects of testing are generally larger for teachers with a B.A. than for those with more education or experience, consistent with the notion that entry wages should change the most in response to barriers. Similarly, the effects are larger in the sample of districts that have new or inexperienced teachers than in the full sample of districts. ${ }^{13}$

Finally, it is worth repeating that the first-stage estimates of the effect of testing requirements in Table 3 are on the order of 50 percentage points. This implies that two-stage least squares (2SLS) estimates of the effect of the use of testing on teacher wages - using state testing regulations as instruments - are about

\footnotetext{
${ }^{12}$ Angus (2001) and Ravitch (2002) argue that teacher certification requirements have been used to control entry into the teaching profession since the mid-19th Century. The major players in the struggle to control entry have been classroom teachers, professors of education and pedagogy, and professors of liberal-arts subjects. Various groups were typically successful at increasing barriers to entry at times of abundant relative teacher supply. For example, testing was a relatively common component of teacher certification in the early part of the $20^{\text {th }}$ century. As World War II drew current and potential teachers to other industries and occupations, however, states recognized districts' need to circumvent the strict licensure requirements. As a result, the use of tests declined dramatically during the war. Note that endogeneity of this sort would tend to bias our estimated wage effects towards zero.

${ }^{13} \mathrm{We}$ also looked at whether testing has a different effect in non-union districts, as suggested by Figlio (2002). We found no clear pattern of differences in impact by union status. It should be noted, however, that the precision of union/non-union interactions is limited by the facts that the SASS collected district union status for only two years and over $70 \%$ of districts are unionized.
} 
twice as large as the reduced-form effects of testing regulations reported in Table $4 .{ }^{14}$

\section{EFFECTS ON QUALITY AND OTHER OUTCOMES}

Although state testing requirements are associated with increased use of teacher tests and with higher teacher wages, there is little evidence that this translates into better teachers, at least along the quality dimensions we can measure. For example, columns 1-4 of Table 5 show no clear pattern of an association between testing requirements and the quality of teacher's undergraduate institutions as measured by average SAT scores. While a required subject test is associated with a marginally significant increase in test scores when both testing requirements are entered jointly and the sample includes districts with inexperienced teachers (column 3), this effect is smaller and insignificant in all other specifications in this sample, and insignificant and negative in the sample of districts with new teachers. Similarly the estimates in columns 5-8 do not point to an association between testing and the quality of teachers' undergraduate institutions as measured by the institutions' classification as a research university or a liberal arts college.

Two other measures of quality, alternative certification and whether teachers majored in their teaching subject, describe teachers' job assignments as opposed to teachers' educational background. Of course, the use of alternative certification methods could be seen as a plus or a minus, depending on the value of traditional certification methods as a quality screen. An important question for our purposes, however, is whether the introduction of tests is confounded with other sorts of licensing reforms. As it turns out, alternative certification is uncorrelated with testing requirements. This suggests that it is reasonable to look at testing requirements in isolation.

In contrast with the alternative certification results, the probability that a teacher majored in their

\footnotetext{
${ }^{14}$ The resulting 2 SLS estimates need not capture the average causal effect of licensing on wages since the amount teachers must be compensated to take a test may be a function of the relative scarcity of non-tested jobs. Assuming such general equilibrium effects are modest, however, the implied 2SLS estimates can be seen as capturing the average causal effect of licensing for districts that would not otherwise chose to test, in a world with the observed baseline prevalence of testing.
} 
teaching subject appears to rise in states that impose a subject test. On the other hand, this effect is not very robust. When estimated in the sample of inexperienced teachers, the imposition of a subject test increases the probability teachers teach in their major by about 2.7 percent, with a standard error of .011 , but the corresponding estimate is about half as large and insignificant in the sample of new teachers.

The last set of estimates looks at the relationship between state testing requirements and the demographic make-up of the teaching labor force. This inquiry is motivated partly by the fact that standardized tests are sometimes thought to be more of a barrier for minorities. The first 4 columns of Table 6 show no relationship between state testing requirements and the percent of new or inexperienced teachers who are black. On the other hand, there is some evidence of a negative association between testing requirements, especially for basic skills, and the number of new teachers who are Hispanic. Columns 5-8 suggest that testing requirements reduce the proportion of new teachers who are Hispanic by about 2 percentage points, a large effect given that only 5 percent of new teachers were Hispanic in 1999-2000. Finally, there is no relationship between testing requirements and the proportion of teachers who are female.

\section{CONCLUSIONS}

Recent years have seen an acceleration in the use of standardized tests when certifying new teachers. Proponents hope these measures will help to maintain quality, but economists have long been skeptical of entry barriers that may shift supply and discourage otherwise qualified applicants. Our investigation of the impact of the use of tests to certify teachers for employment in public schools suggests state requirements increase the use of tests by about 50 percentage points. Testing requirements are also associated with higher teacher wages, consistent with a supply-shift story. Taking estimates from models that control for statespecific linear trends, the reduced form effect of testing on wages is 3-5\%. The implied two-stage least squares effect of the use of tests is twice as large. But there is little evidence of an impact of testing on teacher quality, at least as we measure it. Thus, our results are consistent with the view that testing has acted 
more as a barrier to entry than a quality screen. Another interesting finding is the negative association between teacher testing and probability new teachers are Hispanic.

As a final bit of anecdotal evidence in support of a skeptical view of testing, it is worth observing that while occupational licensing requirements are widespread and apparently increasing, most skilled workers in the private sector are not subject to formal licensing or testing. For example, like many professionals involved in research, American professors are not tested by their universities or even by most (non-civil-service) non-academic employers. ${ }^{15}$

Concerns about testing notwithstanding, the question of how to increase and maintain the quality of the public-sector teacher labor force remains. Ballou's (1996) results indicate that school districts pay surprisingly little attention to the selectiveness of applicants undergraduate institution. Along these lines, Manski (1987) suggested that a floor for teachers' SAT scores could provide a useful screen. A reliance on SATs would appear to avoid some of the problems outlined in our theoretical discussion since this avoids the establishment of a unique barrier to teaching, and may also force school districts to focus more on college quality. This naturally raises the question of whether teachers with higher SAT scores are indeed better teachers, a subject for future research.

\footnotetext{
${ }^{15}$ It may be instructive to compare the relatively free-wheeling US academic labor market with that of Italy and Germany, where faculty are subject to testing. The top Ph.D. programs in the US are full of students from these countries so the undergraduate talent is clearly there. But our impression from discussions with foreign colleagues is that these requirements are widely seen by recent American-trained Ph.D.s as protecting domestically trained and generally less productive incumbents.
} 


\section{Data Appendix:}

The analysis extract was drawn from the Public School Teacher Demand and Shortage Survey (TDSS) component of the Schools and Staffing Survey (SASS). The TDSS is administered to a stratified random sample of school districts in the U.S. The data used in the analysis are from the restricted-use files of the 1987-88, 1990-91, 1993-94 and 1999-2000 waves of the SASS. Individual teacher-level information is extracted from the Teacher Questionnaire of the SASS. Characteristics of colleges attended by teachers are then merged by college FICE codes to the teacher-level data. These data are then weighted by sampling means, aggregated to the district level, and merged to the district-level TDSS. Finally, state-by-year economic measures are merged to the data set. Districts with fewer than 50 students are dropped from the analysis, as are charter districts in the 1999-2000 wave. Throughout the analysis, first-year teachers are defined as teachers who report their first year of teaching to be the year of the survey. Inexperienced teachers are defined as teachers who report their first year of teaching to be less than four years before the year of the survey.

The following definitions were used to create outcome variables extracted from the SASS:

Salary: B.A.: Data come from district-level responses. The base salary paid to a teacher in the district with a Bachelor's of Arts degree, no teaching experience, and no other relevant credentials. Responses are inflated to 1999 dollars using the CPI-U.

Salary: M.A.: Data come from district-level responses. The base salary paid to a teacher in the district with a Master's degree, no teaching experience, and no other relevant credentials. Responses are inflated to 1999 dollars using the CPI-U.

Salary: M.A. + 20 years: Data come from district-level responses. The base salary paid to a teacher in the district with a Master's degree, at least 20 years teaching experience, and no other relevant credentials. Responses are inflated to 1999 dollars using the CPI-U.

Majored in Teaching Subject: Data come from individual teacher responses. A dummy is created that equals one if one of the following three criteria are met: (1) the teacher's primary teaching assignment is Mathematics and he completed either a B.A, M.A. Ph.D. or Education Specialist degree with a major in either Mathematics, Engineering or Economics; (2) the teacher's primary teaching assignment is English and he completed either a B.A, M.A. Ph.D. or Education Specialist degree with a major in English Literature, Letters, Speech, Classics or Composition; (3) the teacher's primary teaching assignment is either Biology, Chemistry, Geology/Earth Science, Physics or General Science and he completed either a B.A, M.A. Ph.D. or Education Specialist degree with a major in either Biology, Chemistry, Geology/Earth Science, Physics, or another Physical Science. This dummy variable is then aggregated using sampling weights to compute the fraction of first-year teachers and inexperienced teachers for which the dummy is equal to one.

Alternative Certification: Data come from individual teacher responses. Teachers are asked what type of state certification they hold in their main assignment field. A dummy is created that equals zero if the teacher describes his certification as either regular, standard or advanced, and one otherwise. This dummy variable is then aggregated using sampling weights to compute the fraction of first-year teachers and inexperienced teachers for which the dummy is equal to one.

The following definitions are used to define hiring-practices variables extracted from the SASS: 
Requires Basic Skills Test: Data are drawn from the TDSS survey of school districts. Districts are asked whether they require teaching applicants to have passed a test of basic skills. A dummy is created which is equal to one if the district requires a state test of basic skills, a district test of basic skills or the National Teachers Exam/Praxis. In some of the analysis, this variable is automatically switched to one if the district is in a state that is mandated by law to require new teachers to pass a standardized test of basic skills.

Requires Subject Test: Data are drawn from the TDSS survey of school districts. Districts are asked whether they require teaching applicants to have passed a test of basic skills. A dummy is created which is equal to one if the district requires a state subject test, a district subject test or the National Teachers Exam/Praxis. In some of the analysis, this variable is automatically switched to one if the district is in a state that is mandated by law to require new teachers to pass a standardized subject test.

The following definitions are used to define quality measures of undergraduate institutions attended by teachers:

Average SAT Score: Data come from a survey conducted by the Higher Education Research Institute. The average combined Math and Verbal SAT score of entering freshman in the fall of 1983 is collected for colleges and universities from college guides and from surveys of college representatives. For schools that do not require students to take the SAT, ACT averages are translated into SAT averages using the following methodology. Samples of students who took both the SAT and ACT, or who took either test and a third common test (the National Merit Scholarship Qualifying Test) are compared. These overlapping samples are used to compute the equivalent percentiles in each test's distribution. ACT scores are then replaced with the corresponding SAT scores at the equivalent point in the distribution.

Attended Research University or Liberal Arts College: A dummy variable is created that equals one if the college attended by the teacher is in one of the following categories of the Carnegie Classification of Institutions of Higher Education (1994 definitions): Research University I, Research University II, or Baccalaureate (Liberal Arts) Colleges I. The three categories included in the dummy are the three nonspecialized categories with average SAT scores greater than 1000.

Information on state testing laws was drawn from the following sources:

Teacher Education Policy in the States: A 50-State Survey of Legislative and Administrative Actions, American Association of Colleges for Teacher Education (Washington, DC: December 1994).

Teacher Education Policy in the States: A 50-State Survey of Legislative and Administrative Actions, American Association of Colleges for Teacher Education (Washington, DC: Spring 1994).

Goertz, Margaret E., State Educational Standards in the 50 States: An Update, Educational Testing Service (Princeton, NJ: March 1988).

Coley, Richard J. and Goertz, Margaret E., Educational Standards in the 50 States: 1990, Educational Testing Service (Princeton, NJ: June 1990).

Rudner, Lawrence M., What's Happening in Teacher Testing: An Analysis of State Teacher Testing Practices, U.S. Department of Education (Washington, DC: August 1987).

The NASDTEC Manual on the Preparation and Certification of Educational Personnel, Kendall/Hunt Publishing Company (Dubuque, IA: 1999). 


\section{REFERENCES}

Angus, David L. (2001), Professionalism and the Public Good: A Brief History of Teacher Certification, ed. Jeffrey Mirel, Washington, DC: The Fordham Foundation.

Astin, Alexander W., Kenneth C. Green, William S. Korn and Mary Jane Maier, The American Freshman: National Norms For Fall 1983, Cooperative Institutional Research Program of the American Council on Education.

Astin, Alexander W. (1971), Predicting Academic Performance in College: Selectivity Data for 2300 American Colleges, New York: The Free Press.

Astin, Alexander W. and James W. Henson (1977), "New Measures of College Selectivity," Research in Higher Education 6, 1-9.

Ballou, Dale (1996), "Do Public Schools Hire the Best Applicants?," The Quarterly Journal of Economics 111, 97-133.

Ballou, Dale and Michael Podgursky (2000), "Gaining Control of Professional Licensing and Advancement," in Tom Loveless, ed., Conflicting Missions? Teachers Unions and Educational Reform, Washington, DC: The Brookings Institution.

Figlio, David (2002), “Can Public Schools Buy Better-Qualified Teachers?," Industrial and Labor Relations Review 55, 686-699.

Friedman, Milton F., and Simon Kuznets (1945), Income from Independent Professional Practice, New York: National Bureau of Economic Research.

Goldhaber, D., \& Brewer, D. (2000), Does teacher certification matter? High school teacher certification status and student achievement, Educational Evaluation and Policy Analysis, 22(2), 129-145.

Guasch, J. Luis and Andrew Weiss (1980), "Wages as Sorting Mechanisms in Competitive Markets with Asymmetric Information," Review of Economic Studies 47, 653-64.

Guasch, J. Luis and Andrew Weiss (1981), "Self-Selection in the Labor Market," American Economic Review 71, 275-84.

Hanushek, Eric A. and Richard A. Pace (1995), "Who Chooses to teach and Why," Economics of Education Review 14, 101-117.

Hanushek, Eric A., John F. Kain, and Steven G. Rivkin (1999), "Do Higher Salaries Buy Better Teachers?,” NBER Working Paper 7082, April.

Kleiner, Morris M. (2000), “Occupational Licensing,” Journal of Economic Perspectives 14, 189-202.

Kleiner, Morris M. and Robert T. Kudrle (2000), "Does Regulation Affect Economic Outcomes? The Case of Dentistry," Journal of Law and Economics 43, 547-82. 
Kleiner, Morris M. and Daniel L. Petree (1988), "Unionism and Licensing of Public School Teachers: Impact on Wages and Educational Output," Chapter 11 in R.B. Freeman and C. Ichniowski, eds., When Public Sector Workers Unionize, Chicago: University of Chicago Press.

Kugler, Adriana, and Robert Sauer (2003), "Doctors Without Borders: The Returns to Professional Licensing for Immigrant Physicians in Israel,” CEPR Discussion Paper 3683, January.

Lelande, Hayne E. (1979), "Quacks, Lemons, and Licensing: A Theory of Minimum Quality Standards," Journal of Political Economy 87, 1328-1346.

Manski, Charles F. (1987), "Academic Ability, Earnings, and the Decision to Become a Teacher: Evidence from the National Longitudinal Study of the High School Class of 1972," in D. Wise (ed.), Public Sector Payrolls, Chicago: University of Chicago Press.

Murnane, Richard J. (1991), Who Will Teach? Policies that Matter, Cambridge: Havard University Press.

National Council for the Accreditation of Teacher Education (1997), Standards, Procedures, and Policies for the Accreditation of Professional Education Units, NCATE: Washington, DC.

Ravitch, Diane (2002), “A Brief History of Teacher Professionalism,” White House Conference on Preparing Tomorrow's Teachers, Washington, DC

Wang, Ruqu (1997), “Competition, Wage Commitments, and Application Fees, “ Journal of Labor Economics 15, 124-142.

Wang, Ruqu, and A. Weiss (1998), "Probation, Layoffs, and Wage-Tenure Profiles: A Sorting Explanation," Labour Economics 5, 359-383. 
Table 1: Means of Selected Variables

\begin{tabular}{|c|c|c|c|c|c|c|c|c|c|c|c|c|}
\hline & \multicolumn{4}{|c|}{ All Districts } & \multicolumn{4}{|c|}{ Sample with Inexperienced Teachers } & \multicolumn{4}{|c|}{ Sample with First-year Teachers } \\
\hline & $87-88$ & $90-91$ & $93-94$ & 99-00 & $87-88$ & $90-91$ & $93-94$ & $99-00$ & $87-88$ & $90-91$ & 93-94 & 99-00 \\
\hline Unweighted Count & 4,790 & 4,831 & 4,920 & 4,644 & 2,073 & 2,277 & 2,390 & 2,374 & 930 & 1,068 & 1,166 & 1,138 \\
\hline \multicolumn{13}{|c|}{ District Characteristics } \\
\hline Enrollment & 2,751 & 2,826 & 2,976 & 3,402 & 4,069 & 3,943 & 4,372 & 5,257 & 6,257 & 5,405 & 6,365 & 7,855 \\
\hline $\begin{array}{l}\text { Full-time Equivalent } \\
\text { Teachers }\end{array}$ & 158.1 & 159.3 & 159.0 & 211.0 & 227.6 & 218.1 & 227.8 & 320.2 & 343.3 & 293.5 & 327.6 & 470.1 \\
\hline $\begin{array}{l}\text { Frac. w/ } \\
\text { Inexperienced Teachers }\end{array}$ & .401 & .426 & .427 & .446 & 1 & 1 & 1 & 1 & 0 & 0 & 0 & 0 \\
\hline $\begin{array}{l}\text { Frac. w/ } \\
\text { First-year Teachers }\end{array}$ & .164 & .194 & .186 & .192 & 0 & 0 & 0 & 0 & 1 & 1 & 1 & 1 \\
\hline \multicolumn{13}{|c|}{ Teacher Wage and Quality Measures } \\
\hline Salary: B.A. & 25,344 & 25,481 & 25,320 & 25,898 & 25,071 & 25,009 & 24,883 & 26,074 & 25,076 & 24,680 & 24,724 & 26,232 \\
\hline Salary: M.A. & 27,683 & 27,765 & 27,649 & 28,303 & 27,327 & 27,265 & 27,150 & 28,489 & 27,335 & 26,965 & 27,020 & 28,673 \\
\hline $\begin{array}{l}\text { Salary: M.A. + } 20 \text { years } \\
\text { experience }\end{array}$ & 41,939 & 42,529 & 42,950 & 44,108 & 40,992 & 41,250 & 41,478 & 43,948 & 41,145 & 40,415 & 41,213 & 43,777 \\
\hline Average SAT & 907.4 & - & 909.9 & 905.2 & 905.7 & - & 906.5 & 907.5 & 912.6 & - & 908.8 & 910.5 \\
\hline $\begin{array}{l}\text { Attended Research Univ. } \\
\text { or Liberal Arts Coll. }\end{array}$ & .218 & - & .227 & .210 & .229 & - & .220 & .214 & .264 & - & .256 & .213 \\
\hline $\begin{array}{l}\text { Majored in Teaching } \\
\text { Subject }\end{array}$ & .067 & .065 & .074 & .077 & .075 & .079 & .095 & .109 & .075 & .079 & .092 & .123 \\
\hline $\begin{array}{l}\text { Frac. w/ Alternative } \\
\text { Certification }\end{array}$ & .104 & .075 & .084 & .116 & .306 & .316 & .287 & .402 & .369 & .382 & .377 & .516 \\
\hline \multicolumn{13}{|c|}{ Other Teacher Characteristics } \\
\hline Fraction Female & .693 & .677 & .662 & .695 & .720 & .666 & .645 & .666 & .700 & .647 & .634 & .676 \\
\hline Fraction Black & .026 & .029 & .025 & .028 & .024 & .018 & .027 & .036 & .024 & .022 & .047 & .042 \\
\hline Fraction Hispanic & .015 & .018 & .020 & .029 & .025 & .027 & .044 & .043 & .021 & .048 & .056 & .050 \\
\hline
\end{tabular}

Notes: District-weighted means are reported. Inexperienced teachers are defined as teachers with less than 4 years teaching experience. All salaries are reported in 1999 dollars. Average SAT, Fraction of Teachers who Attended Carnegie I Schools, and Fraction of Teachers with Alternative Certification are measured for all teachers, inexperienced teachers or first-year teachers. For all other variables, district means are estimated using all schools or using the sample of schools that employ either inexperienced or first-year teachers. 
Table 2: Testing Requirements and Prevalence

\begin{tabular}{|c|c|c|c|c|c|c|c|c|}
\hline & \multicolumn{4}{|c|}{ Proportion of Districts } & \multicolumn{4}{|c|}{ Proportion of States } \\
\hline & $87-88$ & $90-91$ & $93-94$ & $99-00$ & $87-88$ & $90-91$ & $93-94$ & $99-00$ \\
\hline \multicolumn{9}{|l|}{ State Requirements } \\
\hline $\begin{array}{l}\text { Requires Basic } \\
\text { Skills Test }\end{array}$ & .429 & .622 & .697 & .648 & .431 & .588 & .627 & .667 \\
\hline $\begin{array}{l}\text { Requires Subject } \\
\text { Test }\end{array}$ & .336 & .365 & .538 & .674 & .373 & .373 & .529 & .608 \\
\hline Requires Any Test & .540 & .693 & .736 & .820 & .529 & .647 & .667 & .803 \\
\hline \multicolumn{9}{|c|}{ District Response in the SASS } \\
\hline $\begin{array}{l}\text { Uses Basic Skills } \\
\text { Test }\end{array}$ & .361 & .425 & .493 & .646 & & & & \\
\hline Uses Subject Test & .243 & .341 & .394 & .552 & & & & \\
\hline Uses Any Test & .379 & .452 & .514 & .669 & & & & \\
\hline \multicolumn{9}{|c|}{$\begin{array}{l}\text { District Response in the SASS with State } \\
\text { Requirements Imposed }\end{array}$} \\
\hline $\begin{array}{l}\text { Uses Basic Skills } \\
\text { Test }\end{array}$ & .554 & .726 & .778 & .827 & & & & \\
\hline Uses Subject Test & .494 & .613 & .703 & .799 & & & & \\
\hline Uses Any Test & .612 & .744 & .802 & .880 & & & & \\
\hline
\end{tabular}

Notes: The first 4 columns report weighted fractions of districts. The top panel reports fraction (of states or districts) that require new teachers to pass basic skills and/or subject tests to be licensed. The middle panel reports the fraction of districts that report in the SASS that they require teaching candidates to have passed basic skills and/or subject tests. The bottom panel reports the fraction of districts that either report in the SASS that they require teaching candidates to have passed basic skills and/or subject tests or are in a state that requires that they do so. 
Table 3: First-stage estimates with state and year fixed effects

\begin{tabular}{|c|c|c|c|c|c|c|c|c|}
\hline & \multicolumn{4}{|c|}{ District Requires Basic Skills Test } & \multicolumn{4}{|c|}{ District Requires Subject Test } \\
\hline & (1) & $(2)$ & (3) & (4) & (5) & (6) & $(7)$ & $(8)$ \\
\hline & \multicolumn{8}{|c|}{ Full sample } \\
\hline $\begin{array}{l}\text { Basic Skills } \\
\text { Test Law }\end{array}$ & $\begin{array}{l}.516 \\
(.050)\end{array}$ & & $\begin{array}{l}.487 \\
(.053)\end{array}$ & & $\begin{array}{l}.335 \\
(.061)\end{array}$ & & $\begin{array}{l}.143 \\
(.044)\end{array}$ & \\
\hline $\begin{array}{l}\text { Subject } \\
\text { Test Law }\end{array}$ & & $\begin{array}{l}.297 \\
(.070)\end{array}$ & $\begin{array}{l}.081 \\
(.049)\end{array}$ & & & $\begin{array}{l}.588 \\
(.056)\end{array}$ & $\begin{array}{c}.525 \\
(.060)\end{array}$ & \\
\hline $\begin{array}{l}\text { Any } \\
\text { Test Law }\end{array}$ & & & & $\begin{array}{l}.521 \\
(.060)\end{array}$ & & & & $\begin{array}{l}.549 \\
(.054)\end{array}$ \\
\hline $\begin{array}{l}\mathrm{R}^{2} \\
\mathrm{~N}\end{array}$ & \multicolumn{8}{|c|}{$\begin{array}{c}18,288 \\
\text { Inexperienced Teachers }\end{array}$} \\
\hline $\begin{array}{l}\text { Basic Skills } \\
\text { Test Law }\end{array}$ & $\begin{array}{l}.476 \\
(.048)\end{array}$ & & $\begin{array}{l}.454 \\
(.050)\end{array}$ & & $\begin{array}{l}.275 \\
(.066)\end{array}$ & & $\begin{array}{l}.078 \\
(.047)\end{array}$ & \\
\hline $\begin{array}{l}\text { Subject } \\
\text { Test Law }\end{array}$ & & $\begin{array}{l}.258 \\
(.073)\end{array}$ & $\begin{array}{l}.063 \\
(.055)\end{array}$ & & & $\begin{array}{l}.604 \\
(.064)\end{array}$ & $\begin{array}{l}.570 \\
(.070)\end{array}$ & \\
\hline $\begin{array}{l}\text { Any } \\
\text { Test Law }\end{array}$ & & & & $\begin{array}{c}.482 \\
(.066)\end{array}$ & & & & $\begin{array}{l}.533 \\
(.069)\end{array}$ \\
\hline $\begin{array}{l}\mathrm{R}^{2} \\
\mathrm{~N}\end{array}$ & .719 & \multicolumn{6}{|c|}{$\begin{array}{c}6,476 \\
\text { First-year teachers }\end{array}$} & .617 \\
\hline $\begin{array}{l}\text { Basic Skills } \\
\text { Test Law }\end{array}$ & $\begin{array}{c}.449 \\
(.046)\end{array}$ & & $\begin{array}{l}.433 \\
(.048)\end{array}$ & & $\begin{array}{l}\text { hers } \\
.205 \\
(.062)\end{array}$ & & $\begin{array}{l}.048 \\
(.042)\end{array}$ & \\
\hline $\begin{array}{l}\text { Subject } \\
\text { Test Law }\end{array}$ & & $\begin{array}{l}.221 \\
(.075)\end{array}$ & $\begin{array}{l}.057 \\
(.058)\end{array}$ & & & $\begin{array}{l}.566 \\
(.060)\end{array}$ & $\begin{array}{l}.548 \\
(.063)\end{array}$ & \\
\hline $\begin{array}{l}\text { Any } \\
\text { Test Law }\end{array}$ & & & & $\begin{array}{l}.452 \\
(.065)\end{array}$ & & & & $\begin{array}{l}.466 \\
(.074)\end{array}$ \\
\hline $\begin{array}{l}\mathrm{R}^{2} \\
\mathrm{~N}\end{array}$ & .706 & .622 & .707 & .682 & .539 & .631 & .631 & .595 \\
\hline
\end{tabular}

Notes: Inexperienced teachers are defined as teachers with less than 4 years teaching experience. The table reports OLS estimates of equation (3). The dependent variable is an indicator for whether districts either report in the SASS that they use information on whether teaching candidates passed a basic skills or subject test or are in a state that requires that they do so. Controls include state and year fixed effects, city, suburb and rural fixed effects, a quadratic in the state unemployment rate, district enrollment, and district fraction minority enrollment. All regressions are weighted using district sampling weights. Standard errors corrected for state-by-year correlation in the error term are reported in parentheses. 
Table 4a: Wage Estimates Controlling for State and Year Fixed Effects

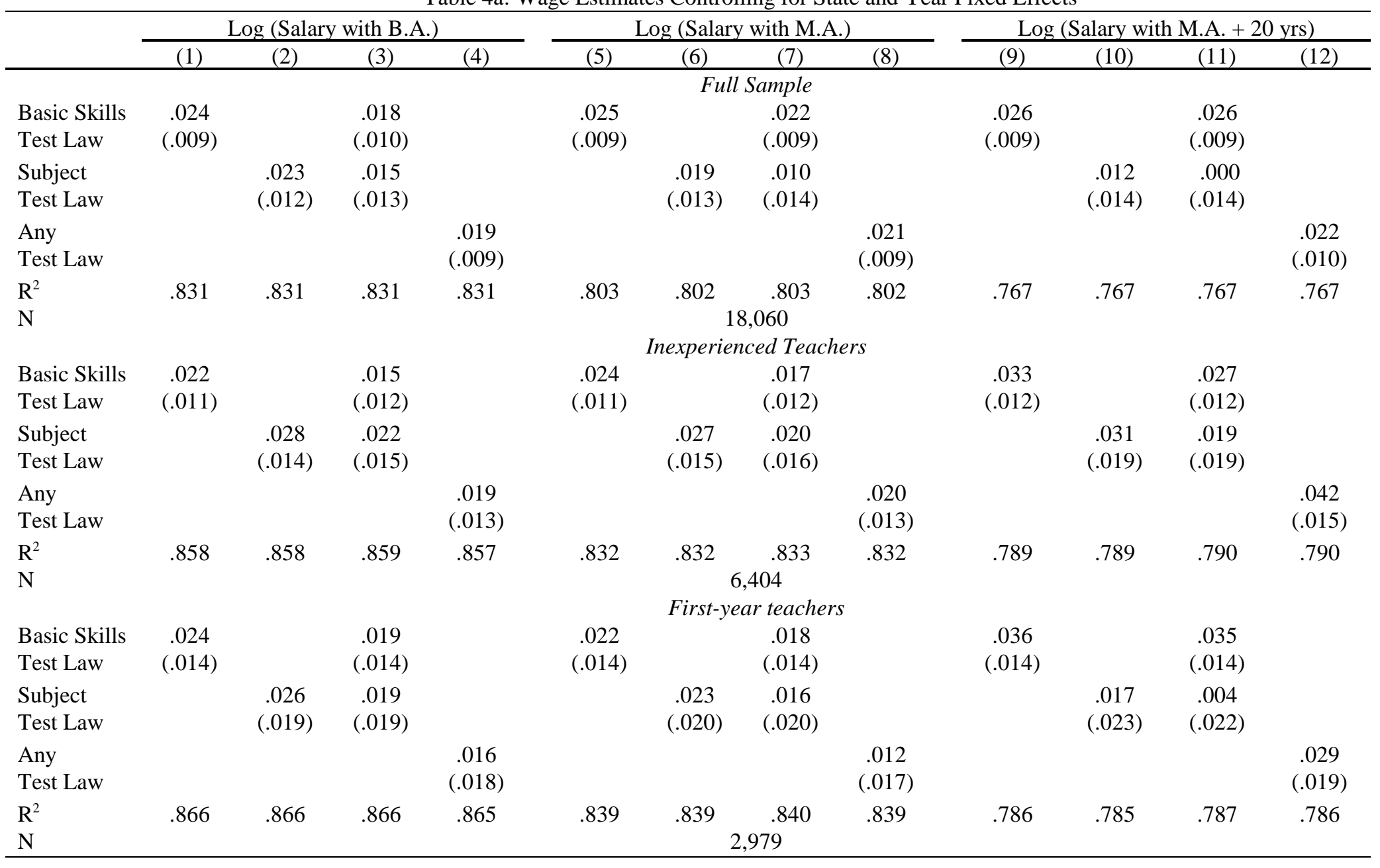

Notes: Inexperienced teachers are defined as teachers with less than 4 years teaching experience. Reported coefficients are estimated from a regression of log salary on state testing requirement dummy variables and a set of controls. Controls include state and year fixed effects, city, suburb and rural fixed effects, a quadratic in the state unemployment rate, district enrollment, and district fraction minority enrollment. All regressions are weighted using district sampling weights. Standard errors corrected for state-by-year correlation in the error term are reported in parentheses. 
Table 4b: Wage Estimates Controlling for State and Year Fixed Effects and State-specific Linear Trends

\begin{tabular}{|c|c|c|c|c|c|c|c|c|c|c|c|c|}
\hline & \multicolumn{4}{|c|}{ Log (Salary with B.A.) } & \multicolumn{4}{|c|}{ Log (Salary with M.A.) } & \multicolumn{4}{|c|}{ Log (Salary with M.A. + 20 yrs) } \\
\hline & $(1)$ & $(2)$ & $(3)$ & $(4)$ & $(5)$ & $(6)$ & $(7)$ & $(8)$ & $(9)$ & $(10)$ & $(11)$ & $(12)$ \\
\hline & \multicolumn{12}{|c|}{ Full Sample } \\
\hline Basic & .033 & & .026 & & .032 & & .025 & & .020 & & .016 & \\
\hline Skills & $(.010)$ & & $(.011)$ & & $(.009)$ & & $(.010)$ & & $(.009)$ & & $(.010)$ & \\
\hline Subject & & .032 & .021 & & & .030 & .019 & & & .020 & .014 & \\
\hline Test Law & & $(.010)$ & $(.011)$ & & & $(.011)$ & $(.011)$ & & & $(.014)$ & $(.014)$ & \\
\hline Any & & & & .029 & & & & .030 & & & & .020 \\
\hline Test Law & & & & $(.009)$ & & & & $(.009)$ & & & & $(.012)$ \\
\hline $\mathrm{R}^{2}$ & .844 & .844 & .845 & .844 & .816 & .815 & .816 & .815 & .775 & .775 & .775 & .775 \\
\hline \multirow[t]{2}{*}{$\mathrm{N}$} & \multicolumn{12}{|c|}{18,060} \\
\hline & \multicolumn{12}{|c|}{ Inexperienced Teachers } \\
\hline Basic & .044 & & .030 & & .044 & & .030 & & .030 & & & \\
\hline Skills & $(.014)$ & & $(.015)$ & & $(.013)$ & & $(.014)$ & & $(.016)$ & & .012 & \\
\hline Subject & & .049 & .037 & & & .050 & .038 & & & .054 & .049 & \\
\hline Test Law & & $(.013)$ & $(.013)$ & & & $(.012)$ & $(.012)$ & & & $(.018)$ & $(.019)$ & \\
\hline Any & & & & .039 & & & & .044 & & & & .050 \\
\hline Test Law & & & & $(.012)$ & & & & $(.012)$ & & & & $(.019)$ \\
\hline $\mathrm{R}^{2}$ & .873 & .874 & .874 & .872 & .847 & .848 & .848 & .847 & .800 & .801 & .801 & .801 \\
\hline \multirow[t]{2}{*}{$\mathrm{N}$} & \multicolumn{12}{|c|}{6,404} \\
\hline & \multicolumn{12}{|c|}{ First-year teachers } \\
\hline Basic & .044 & & .032 & & .042 & & .028 & & .024 & & .010 & \\
\hline Skills & $(.015)$ & & $(.016)$ & & $(.015)$ & & $(.015)$ & & $(.018)$ & & $(.017)$ & \\
\hline Subject & & .049 & .037 & & & .056 & .046 & & & .049 & .045 & \\
\hline Test Law & & $(.017)$ & $(.017)$ & & & $(.016)$ & $(.017)$ & & & $(.028)$ & $(.029)$ & \\
\hline Any & & & & .035 & & & & .040 & & & & .028 \\
\hline Test Law & & & & $(.014)$ & & & & $(.014)$ & & & & $(.022)$ \\
\hline $\mathrm{R}^{2}$ & .886 & .886 & .887 & .885 & .860 & .861 & .861 & .859 & .800 & .801 & .801 & .800 \\
\hline $\mathrm{N}$ & & & & & & & & & & & & \\
\hline
\end{tabular}

Notes: Inexperienced teachers are defined as teachers with less than 4 years teaching experience. The estimates are from models as in Table $4 a$, with the addition of state-specific linear trends. All regressions are weighted using district sampling weights. Standard errors corrected for state-by-year correlation in the error term are reported in parentheses. 
Table 5: Teacher Quality Estimates

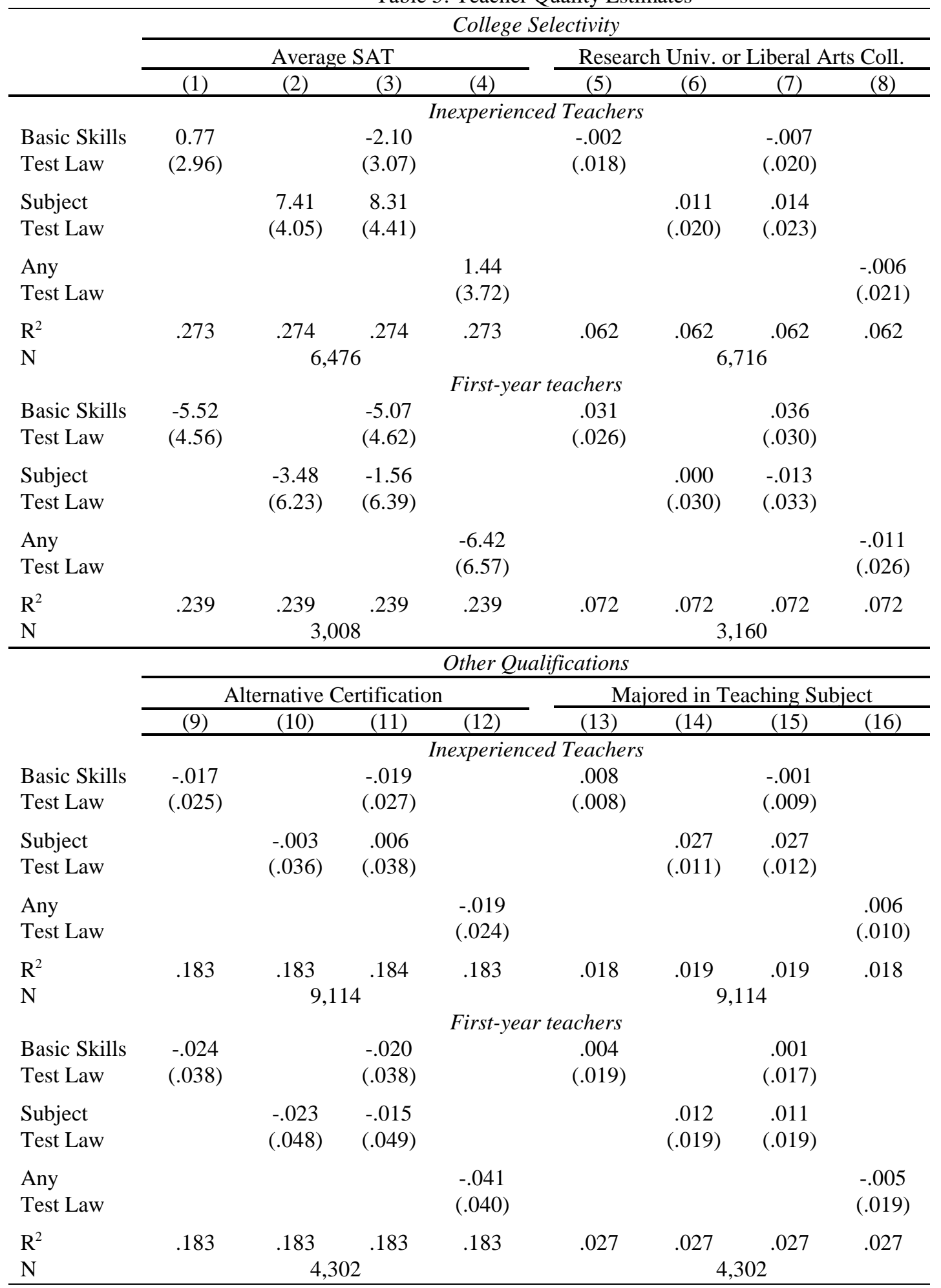

Notes: Inexperienced teachers have less than 4 years teaching experience. Dependent variables are: Average SAT of matriculating freshmen in 1983 at teachers' undergraduate institution; the fraction of teachers that attended colleges in a Carnegie Research University I \& II or Baccalaureate (Liberal Arts) College I; an indicator for whether the teacher was hired without regular state certification (alternatives are temporary certification, provisional certification and emergency certification); the fraction of teachers whose primary teaching assignment is in the same subject as their B.A, M.A., Ph.D or Education Specialist degree major. Controls include state and year fixed effects, city, suburb and rural fixed effects, a quadratic in the state unemployment rate, district enrollment, and district fraction minority enrollment. All regressions are weighted using district sampling weights. Standard errors corrected for state-by-year correlation in the error term are reported in parentheses. There are fewer observations for the Average SAT and Carnegie Type I specifications because the 1990-91 SASS does not report the teacher's undergraduate college. 
Table 6: Teacher Characteristics Estimates

\begin{tabular}{|c|c|c|c|c|c|c|c|c|c|c|c|c|}
\hline & \multicolumn{4}{|c|}{ Fraction Black } & \multicolumn{4}{|c|}{ Fraction Hispanic } & \multicolumn{4}{|c|}{ Fraction Female } \\
\hline & (1) & $(2)$ & $(3)$ & (4) & $(5)$ & $(6)$ & $(7)$ & $(8)$ & (9) & $(10)$ & $(11)$ & (12) \\
\hline & \multicolumn{12}{|c|}{ Inexperienced Teachers } \\
\hline Basic Skills & -.005 & & -.006 & & -.009 & & -.007 & & -.001 & & .004 & \\
\hline Test Law & $(.005)$ & & $(.005)$ & & $(.004)$ & & $(.005)$ & & $(.016)$ & & $(.017)$ & \\
\hline Subject & & .001 & .003 & & & -.008 & -.005 & & & -.016 & -.018 & \\
\hline Test Law & & $(.007)$ & $(.007)$ & & & $(.008)$ & $(.009)$ & & & (.019) & $(.020)$ & \\
\hline Any & & & & -.003 & & & & -.010 & & & & -.003 \\
\hline Test Law & & & & $(.007)$ & & & & $(.005)$ & & & & $(.016)$ \\
\hline $\mathrm{R}^{2}$ & .141 & .141 & .141 & .141 & .081 & .081 & .081 & .081 & .032 & .032 & .032 & .032 \\
\hline \multirow[t]{2}{*}{$\mathrm{N}$} & \multirow{2}{*}{\multicolumn{4}{|c|}{9,114}} & \multicolumn{4}{|c|}{9,114} & \multirow{2}{*}{\multicolumn{4}{|c|}{9,114}} \\
\hline & & & & & \multicolumn{4}{|c|}{ First-year teachers } & & & & \\
\hline Basic Skills & -.002 & & -.005 & & -.020 & & -.016 & & -.012 & \multirow{2}{*}{\multicolumn{3}{|c|}{$\begin{array}{l}-.009 \\
(.025)\end{array}$}} \\
\hline Test Law & $(.007)$ & & $(.007)$ & & $(.008)$ & & $(.009)$ & & $(.026)$ & & & \\
\hline Subject & & .008 & .010 & & & -.019 & -.013 & & & -.012 & -.008 & \\
\hline Test Law & & $(.011)$ & $(.011)$ & & & $(.013)$ & $(.014)$ & & & (.029) & $(.027)$ & \\
\hline Any & & & & .006 & & & & -.021 & & & & -.023 \\
\hline Test Law & & & & $(.009)$ & & & & $(.009)$ & & & & $(.027)$ \\
\hline $\mathrm{R}^{2}$ & .162 & .162 & .162 & .162 & .126 & .126 & .126 & & .042 & .042 & .042 & .042 \\
\hline $\mathrm{N}$ & \multicolumn{4}{|c|}{4,302} & \multicolumn{4}{|c|}{4,302} & \multicolumn{4}{|c|}{4,302} \\
\hline
\end{tabular}

Notes: Inexperienced teachers are defined as teachers with less than 4 years teaching experience. Dependent variables are the fraction of inexperienced or first-year teachers in the district who fall into the respective category. Reported coefficients are estimated from an OLS regression on state testing requirement dummy variables and a set of controls. Controls include state and year fixed effects, city, suburb and rural fixed effects, a quadratic in the state unemployment rate, district enrollment, and district fraction minority enrollment. All regressions are weighted using district sampling weights. Standard errors corrected for state-by-year correlation in the error term are reported in parentheses. 